\title{
The role and significance of Russian doctrinal documents, with particular focus on information security doctrines from 2000 and 2016
}

Zarys treści: Autor artykułu stawia sobie za zadnie przeanalizowanie roli rosyjskich dokumentów doktrynalnych oraz ich wartości dla analizy polityki rosyjskiej. Podkreśla ciągłość sowieckiej i rosyjskiej myśli wojskowej, która znajduje odzwierciedlenie m.in. w sposobie formułowania i używania przez Rosję dokumentów doktrynalnych. Na przykładzie wspomnianych dokumentów podkreśla on ofensywny charakter działań Kremla, który pod pretekstem obrony rosyjskiej tożsamości realizuje starą politykę imperialną.

Outline of content: The author of the article undertakes the task of examining the role of Russian doctrinal documents and their value for the analysis of Russian politics. He underlines the continuity of the Soviet and Russian military thought, reflected also in the way Russia formulates and uses doctrinal documents. Using the example of these documents, he emphasises the offensive character of Kremlin's actions, which under the pretext of defending Russian identity implements the old imperial policy.

Słowa kluczowe: ZSRR, doktryna wojenna Federacji Rosyjskiej, doktryna informacyjna, dezinformacja, strategia informacyjna, rosyjska narracja polityczna, Russkiy Mir, sowietologia

Keywords: USSR, Russian Federation military doctrine, information doctrine, disinformation, information strategy, Russian political narration, Russkiy Mir, Sovietology

\section{Introduction}

Since the 1930s, Sovietologists have emphasised that the leadership of the Union of Soviet Socialist Republics was guided by Carl von Clausewitz's classic principle in its foreign politics: "War is merely the continuation of policy by other means". ${ }^{1}$

${ }^{1}$ C. Clausewitz, O wojnie, Warszawa, 2010, p. 29. 
Vladimir Lenin was a proponent of such a definition of war. ${ }^{2}$ Clausewitz's fluid boundary between the state of war and peace was also reflected in Soviet military thought, where political and military strategy merged and subjugated to an expansive communist ideology, which assumed continuous confrontation of the "capitalist world" with the communist bloc. ${ }^{3}$ This scheme of understanding reality still forms the basis of the Russian military and political thought.

In the 1980s, as a result of considerable technological and economic underdevelopment in relation to the West, a system transformation was introduced in the USSR. Communism ceased to be an ideology binding the multinational state. In 1986 Alain Besançon pointed out that "If you destroy the ideology, the Great Russian nation will have nothing to replace it with". ${ }^{4}$ The Soviet elite seemed aware of it too, and in parallel with the process of perestroika took action to maintain dominance over the nations of the Eastern Bloc - the end of the USSR did not mean the end of Russian imperial aspirations. ${ }^{5}$ Formulation of the new imperial ideology was aided by Russian emigrants, who in their academic and political concepts often sought some other form of consolidating the Empire, rather than through communist ideology. ${ }^{6}$ The unity and indivisibility of Russian territories, often sacralised, was a value beyond any doubt, both among the Russian emigration and the population of the USSR, with certain exceptions. ${ }^{7}$ A synthesis of post-Soviet

2 One of the first to emphasise this fact were Polish Sovietologists Jerzy Niezbrzycki (aka Ryszard Wraga), and Włodzimierz Bączkowski: R. Wraga, "Gwarancje Pana Otmara", Bunt Młodych, 13 May 1935, no. 10, pp. 4-5; id., Geopolityka, strategia i granice, Tel Aviv, 1943, p. 21; W. Bączkowski, "Uwagi o istocie siły rosyjskiej", Wschód-Orient, 1938, no. 4, http://www.omp.org.pl/ artykul.php?artykul=115 (accessed: 13 April 2017); id., Rosja wczoraj i dziś, Jerozolima, 1946, p. 17. Over time, this view entered the canon of global Sovietology: R.L. Garthoff, Soviet military doctrine, Illinois, 1953, p. 10.

${ }^{3}$ Following Lenin, key Soviet military theorists who referred to Clausewitz, included: Mikhail Frunze, Alexander Svechin, Mikhail Tukhachevsky and others; Garthoff, Soviet military doctrine, p. 12.

4 A. Besançon, "Imperium rosyjskie i panowanie sowieckie", in: Sowietskij Sojuz. Wybór, eds. J. Karpiński, I. Lasota, Wrocław, 1989, p. 18.

5 Robert A. Jones rightly noted that a return to the Brezhnev doctrine (of limited sovereignty) was not impossible, R.A. Jones, The Soviet Concept of "Limited Sovereignty" from Lenin to Gorbachev: The Brezhnev Doctrine, London, 1990, pp. 260-261.

6 The Eurasian concept, formulated in the 1920s by Petr Savitsky in emigration, gained popularity with time. The far-reaching character of this idea was quickly appreciated by the Bolsheviks, who used it to attract emigrants back to the USSR, presented as the Eurasian empire. The most famous researcher of this concept was Lev Gumilyov (who had the opportunity to meet Savitsky in a labour camp). Currently the most famous exponent of this concept in Russia is Aleksandr Dugin, who refers to Gumilyov, while Eurasianism has become a carrier for Russian imperial ambitions.

7 Attachment to what Russian propaganda today calls the Russkiy Mir has been presented by one of the most well-known emigrants Alexander Solzhenitsyn in his emigration papers. In 2000, he spoke to the newly elected president Vladimir Putin, who used his authority and views as a component of a new state ideology that assumed not only the rebuilding of the empire, but also 
and pre-revolutionary legacy very clearly emerged under President Vladimir Putin, however the foundation had been prepared already in the days when the General Secretary of the Communist Party of the Soviet Union was Mikhail Gorbachev. ${ }^{8}$

The nineties were seen by the Russians as a period of their humiliation, poverty, corruption, "expansion" of NATO, weakened power and fear of terrorist attacks. These factors have allowed the ruling elites to boost the conviction within the society that Russia continues to face a threat from the West. Russia, experiencing a period of weakness, was unable to prevent the access of former Eastern Bloc states into the structures of NATO and the EU. It does not mean that it has accepted this fact; on the contrary, it began looking for ways to effectively reverse this process. Methods the Russian authorities intended to apply are reflected in the seemingly defensive doctrinal documents (particularly information doctrines, best illustrating the specificity of Russian way of thinking), whose role and importance will be discussed in this article.

\section{Narration in the official military doctrines of the Russian Federation}

The first doctrinal document written in the Russian Federation (RF) was The Basic Provisions of the Military Doctrine of the Russian Federation of 2 November 1993.9 One of the most important messages the Federation wanted to communicate to the West was that it reserved the right to intervene in countries where the Russian

taking over the leading position among other nations from the West, in accordance with Solzhenitsyn’s thought. P. Głuszkowski, Antyrosja. Historyczne wizje świata Aleksandra Sołżenicyna. Próba polskiego odczytania, Warszawa, 2008, pp. 37-39. In the results of a general referendum, 71.3\% of voters were in favour of maintaining the USSR; B. Gołąbek, Lew Gumilow i Aleksander Dugin. O dwóch obliczach euroazjatyzmu w Rosji po 1991 roku, Kraków, 2012, p. 9.

${ }^{8}$ Lev Gumilyov forged all his ideas in the USSR. However, he became known to wider than academic audiences only in 1989 (thanks to programmes of the Leningrad Television); Gołąbek, Lew Gumilow, p. 10. In the same period, Dugin began building a network of foreign influences, referring to the legacy of Gumilyov; he was particularly active in terms of ideological diversion among Western elites. For more see M. Wojnowski, "Koncepcja wojny sieciowej Aleksandra Dugina jako narzędzie realizacji celów geopolitycznych Federacji Rosyjskiej”, Przegląd Bezpieczeństwa Wewnętrznego, 16 (2017), pp. 25-26. An important émigré whose activity was used to build a new ideology was Nikita Struve, son of the famous academic and politician Peter Struve. In 1990 the former became involved in the return of emigrants to Russia; from 1991 onwards, within the initiative "Russkiy Put" he established a network of reading rooms in the Commonwealth of Independent States and the Baltic states, and in 1995 started Библиотеку-фонд "Русское Зарубежье", which became one of the instruments for consolidating the Russian diaspora and promoting new ideology, http://www.rp-net.ru/book/OurAutors/struve/index.php (accessed: 17 May 2017).

9 Основные положения военной доктрины российской федерации, 2 November 1993, http:// studydoc.ru/doc/360885/osnovnye-polozheniya-voennoj-doktriny-rossijskoj-federacii (accessed: 13 April 2017). 
minority would be repressed, and that it did not consent to the stationing of NATO troops in countries considered by Russia its safety zone. The document emphasised the willingness to cooperate in building international security and to further reduce nuclear arsenal (reserving the right to a nuclear response to a conventional attack). Officially, the doctrine was defensive, however in practice it showed that Russia would seek to apply the principle of limited sovereignty to the states of the former Eastern Bloc. The most serious threats included repressing the Russian minority and separatist movements, pointing indirectly to elements on which it based its aggressive policy towards the countries of the former USSR in later years. ${ }^{10}$ It is worth noting that, along with the doctrine, a number of the Russian Military Digest was issued, focusing on the discussion surrounding the Russian military doctrine in 1911-1939. ${ }^{11}$ Three chapters on Russia: tsarist, Soviet and foreign ("White" emigration) showed the synthetic nature of Russian identity and the continuity of its military thought.

The Military Doctrine of the Russian Federation, approved on 21 April 2000, once again highlighted its transitional character (connected to "building democracy") and defensive nature. The introduction noted that the doctrine intended to centralise the state and military control in the sphere of politics, diplomacy, economy, society, information, law, army, and other. It estimated that the probability of the outbreak of a global conflict, including a nuclear one, was low. ${ }^{12}$ It expected greater intensity of various extremist and separatist movements, local wars, the arms race, the proliferation of nuclear weapons and other weapons of mass destruction, as well as "increased information confrontation". The elements destabilising the international situation were to be: a marginalised role of the UN and the OSCE, armaments incompatible with international agreements, the use of information technologies for expansion, the activities of extremist groups (nationalist, religious, separatist, terrorist). In terms of external risks, the document focused on listing activities which may take place without an official state of war or within the local war (such as informational and technical, or informational and psychological activities), including: "attempts to ignore (diminish) the Russian Federation's interest in deciding on matters of international security, to ensure that it does not strengthen its position as one of the influential centres of a multi-polar

${ }^{10}$ Using the Russian minority and representatives of the peoples identifying with the Russkiy Mir, separatist and opposition movements (in accordance with the old methods of tsarist Okhrana) is a permanent instrument of the Russian foreign policy (tense situation in the Baltic states, closer relations with Belarus and Transnistria, military actions in Georgia and Ukraine, favouring the politicians who support Russia).

11 Русская Военная Доктрина. Материалы дискуссий 1911-1939 годов, изд. А. Савинкин, Москва, 1994. Work registered on 29 October 1993 in the Moscow regional inspection of the freedom of the press and mass information. The volume was released in the series of Russkiy Put, whose founders included Nikita Struve.

12 Военная доктрина Российской Федерации, 21 April 2000, http://www.ng.ru/politics/2000-04-22/5_doktrina.html (accessed: 13 April 2017). 
world". ${ }^{13}$ The last paragraph of the doctrine emphasises that the Federation's aim is to prevent conflicts and promote international security and peace.

The Military Doctrine of the Russian Federation from 2010 repeated the argument about the increase of regional conflicts. ${ }^{14}$ It also included a statement that the existing security architecture did not provide it equally to all states; it was noted that the war threat towards Russia increased i.a. due to the breach of international law by NATO and attempts to include countries bordering the Russian Federation into the Alliance, attempts to destabilise countries and regions and undermining strategic stability, placing foreign troops in countries neighbouring Russia, deployment of missile defence systems, territorial claims towards Russia and its allies, non-compliance with international agreements, escalation of conflicts in the regions bordering Russia, the spread of international terrorism and separatism. The conflicts' specific character was to be the unpredictability of their outbreak, a wide range of fighting measures used, including information confrontation to achieve political objectives without war. In the context of information, the doctrine contained a statement about the need to develop forces and means of information confrontation, based on modern technologies.

The Military Doctrine of the Russian Federation of $2014^{15}$ once again lists global competition and regional conflicts in the section on threats. A large military conflict involving Russia was described as unlikely, while increased risk in the area of information was stressed. NATO is once more indicated as the main threat, followed by, in order: internal destabilisation in individual countries, increased foreign military contingents in countries bordering Russia, developing strategic missile defence systems, and finally the use of information technologies for military and political purposes and installing regimes opposing Russia in countries it borders. Among the major internal war dangers, the first one to be mentioned was actions leading to overthrowing the constitutional regime, destabilising the internal political situation, and disorganising the functioning of state authorities and infrastructure, including information infrastructure. Threats listed next were: the activities of terrorist organisations; the informational impact on the society, in particular the youth, aiming to disrupt the historical, spiritual and patriotic traditions in terms of defending the homeland; provoking religious, ethnic, social and religious tensions. War threats included: sudden aggravation of the military and political situation and creating the conditions for using military force; interfering with the work of national and military management systems of the Russian Federation; creating and training illegal armed formations with the purpose of using them against Russia or its allies; military demonstration at the time of manoeuvres on the territory of

13 Ibid.

14 Военная доктрина Российской Федерации, 5 February 2010, http://kremlin.ru/supplement/461 (accessed: 24 March 2017).

15 Военная доктрина Российской Федерации, 26 December 2014, pp. 4-7, http://kremlin.ru/events/ president/news/47334 (accessed: 13 April 2017). 
countries bordering the Federation and its allies; individual countries activating their armed forces (partial or general mobilisation, a country on a war footing).

This brief review of the threats contained in the Russian military doctrines aims to indicate that, despite the distinct function the doctrines have in Russia (an instrument for informational impact used in accordance with a long-term strategy which is not explicitly formulated), a close reading can show the consistency and long-term nature of Russia's actions, and the characteristic elements of the Russian thought. Basic assumptions of the 1993 doctrine have remained unchanged and have merely been updated, expanded or otherwise included in the subsequent documents, depending on the needs of foreign policy. They demonstrate the way Russia uses doctrines to exert influence through information, for both internal and external purposes. ${ }^{16}$ In each of the subsequent doctrines, external communications stressed, with increasing strength, Russia's right to exert the same influence as the Soviet Union (element of deterrence). Internally, it has been seeking the maximum consolidation of the society and producing an image of two worlds: of Russia and its allies (Russkiy Mir / the Eurasian Union / the Fourth Political Theory are alternates directed to respective audiences) $)^{17}$ as the defenders of civilisation, and the Euro-Atlantic camp, portrayed as the aggressor threatening the world order. ${ }^{18}$ The defensive-dissuasive rhetoric and constructing an image of NATO as an organisation contributing to the destabilisation of the global situation is designed to detract from the moral supremacy of the Euro-Atlantic camp. Such a narrative also aims to create an impression that Russian actions are reactive

16 Jolanta Darczewska distinguishes four functions of the Russian strategic documents: worldview, methodological, educational/didactic and mobilisational (the prognostic function is marginal). According to the researcher, these documents form a part of an information strategy and fulfil functions distinct from Western documents, J. Darczewska, Rosyjskie sity zbrojne na froncie walki informacyjnej. Dokumenty strategiczne (series: Prace OSW, no. 57), Warszawa, 2016, p. 22. The specificity of the current Russian doctrines does not deviate from the standards used in the USSR; according to Laurence Martin, Soviet doctrines were "to manipulate the enemy rather than merely to subdue him [...]", L. Martin, "The Influence of Soviet Military Doctrine on Western Strategy", in: Soviet Military Doctrine and Western Policy, ed. G. Flynn, London, 1989, p. 406.

17 A similar role was played by the collection programme of the Ruthenian lands, followed by pan-Slavism and communism, subsequently abandoned due to their anachronism or ineffectiveness. Today, they perform only auxiliary functions. The prominent Polish Sovietologist Ryszard Wraga noted that the 19th century was for Russia a time of seeking an idea that would enable it to implement the empire's construction more fully - this statement can also be applied to the 20th century, R. Wraga, Geopolityka, strategia i granice, Roma, 1945, p. 11.

18 The scheme of the confrontation of the two civilisations was developed in the Russkiy Mir doctrine, drawn up by the members of the Izborsk Club, founded in 2012: Доктрина Русского мира, авторский коллектив доклада: В. Аверьянов (автор-составитель), С. Баранов, А. Гапоненко, А. Елисеев, А. Комогорцев, А. Стариков, 26 September 2016, https://izborskclub.ru/10269 (accessed: 17 May 2017). The very idea of writing such a doctrine was revealed in 2005 by Vitaly Averianov, acting within the Sergiev project supported by the Orthodox Church, http://www.rusdoctrina.ru/page95504.html (accessed: 17 May 17 2017). 
in relation to the actions of the aggressive North Atlantic Alliance, according to the enforced message. Through doctrines whose message is synergistically linked to the message of the decision-makers, politicians, the media and other entities creating its information policy, Russia introduces a cognitive dissonance in its opponents and tries to gain informational advantage (enforcing its own narrative to Western societies). The confusion concerning the recognition of Russian intentions, introduced through official doctrinal documents can be a threat to politicians, analysts or academics who in their work will not take into account the dual nature of the official Russian documents. ${ }^{19}$ Although Russia is unable to dominate Western communications; it can affect them in points and in the short-term; over time, long-term influence can also provide fertile ground for its narratives in specific issues in a given country (including Poland).

How false the "flip side" presented in Russian doctrinal documents is can be shown through a close reading of specialist publications from the area of Russian/Soviet military studies. In this context, it is worth quoting a paper by Captain Dmitry Chuvatkin, an employee of the Perm Military Institute of the Internal Troops of the Ministry for Internal Affairs, entitled: The war doctrine as information impact (semiotic approach), ${ }^{20}$ which has been presented at a specialist conference in Barnaul. Both the place, the auditorium and the speaker (a mere captain) allow to say that the presented paper expressed common views, at least in the circles of the services with a decisive influence on the processes taking place in Russia. A reading of the paper shows that its author's approach is embedded in the theses of Clausewitz, assimilated by the Bolsheviks and still popular in the Russian academia: "[...] after analysing the basic military and political orientations and directions it becomes clear that the military doctrines are not only defensive in nature, but they are focused on a broad use of military force as a conclusive instrument of foreign policy" [translated by $\mathrm{\ell D}]{ }^{21}$ In other words, each military doctrine is offensive a priori, since the use of force is only the next step in the foreign policy, and there is no clear distinction here between the stages of peace and war, as the only thing that counts is the objectives one wants to achieve, while the choice of measures is of technical importance. This perception of the doctrine allows us to claim that Russia does not stop at theory, but that its doctrines are in

19 The problem lies i.a. in different interpretations of the same terms. The Russian Federation is keen on using Western terminology in order to mislead other countries, a standard practice since the USSR era - "You have to know that Soviet (communist) propaganda is extremely eager to introduce chaos into the concepts adopted by humanity. The official communist doctrine supports itself with a large number of names which, not only in practice but also in communist theory mean something quite different to the humanistic vocabulary of the free world", R. Wraga, “O tak zw. 'komunizmie narodowym”, Syrena, no. 48, 1 December 1956.

20 Д.Н. Чубаткин, “Военная доктрина как способ информационного воздействия (семиотический подход)”, in: Современная Россия и мир: альтернативы развития (Информационные войны в международных отношениях), ред. Ю.Г. Чернышов, Барнаул, 2012, pp. 136-140.

${ }^{21}$ Ibid., p. 137. 
fact offensive in nature. What purpose does the official doctrine serve? The answer formulated by Chuvatkin is clear: "the war doctrine [is] a system of ideas, compiled in the framework of a semiotic paradigm. [...] This makes the war doctrine of a modern state a weapon in the information war [...] The idea of information impact involves instilling in a potential opponent a programmed (controlled) informational image of the world, a way of thinking. It has become obvious that the information impact is able to change the main military and political resource of a country - the national mentality, culture, morality and the will of the people. In this way, the question about the role of the symbolic capital of culture in the information space ceases to be an abstract or theoretical one, and takes on strategic political importance" [translated by $€ D$ ]. ${ }^{22}$ Such approach stems from both the Eastern traditions of the way Russian state functions, deeply rooted in the history, and the very advanced research into the human psyche, which has led to the development of reflexive control methodology, applied on all levels of human activities as well as state activities in Russia. ${ }^{23}$ Considering the specific nature of the Russian approach, we can analyse the doctrines of the Russian Federation's information security particularly from this perspective.

\section{Russian Federation information security doctrines of 2000 and $2016^{24}$}

When comparing the two documents, we quickly notice that the 2000 doctrine has a more complex structure, compared with the much shorter, more general and accusatory in its tone doctrine of 2016. In both documents, the national interest has been defined as: the defence of the Russian Federation's information sovereignty, protection of the constitutional rights and freedoms of the individual and citizen in the area of acquiring and using information, using information technologies,

22 Ibid., p. 138.

${ }^{23}$ More on the reflexive control theory in Russian military sciences see: M. Wojnowski, "Zarządzanie refleksyjne' jako paradygmat rosyjskich operacji informacyjno-psychologicznych w XXI w.”, Przegląd Bezpieczeństwa Wewnętrznego, 12 (2015), pp. 11-36, C. Reid, Reflexive Control in Soviet Military Planning, in: Soviet Strategic Deception, eds. B.D Dailey, P.J. Parker, Toronto, 1987, pp. 295-311.

${ }^{24}$ In both the documents, the infosphere is a combination of information, computerisation tools, information systems, websites, connection networks, information technologies, instruments for constructing and processing information, development and use of technologies, providing information security and the complexity of mechanisms regulating mutual social relations (the global and cross-border nature of threats in the infosphere has been stressed), Доктрина информационной безопасности Российской Федерации, 9 September 2000, http:// primorsky.ru/authorities/executive-agencies/departments/information-security/Documents/dokipo-ib (accessed: 9 January 2017); Доктрина информационной безопасности Российской Федерации, 5 December 2016, p. 1, 3, 5, http://www.scrf.gov.ru/documents/6/5.html (accessed: 9 January 2017). 
information support for democratic institutes, mechanisms of mutual interaction between the state and the civil society, assimilation of information technology for the protection of the culture, historical and spiritual values of the multinational nation of the Russian Federation (a term related to the ideology of Russkiy Mir), protection of information infrastructure, developing the information technology sector and electronic industry in the Federation, delivery of reliable information to the internal and external recipient, support in building an international information security system. ${ }^{25}$

In the doctrine of 2000, the threats to the security of the Russian Federation are divided in the subsection "Types of threats to information security of the Russian Federation" into the following four categories of threats: "to the constitutional rights and freedoms of the individual and the citizen in the sphere of spiritual life and information activities for individual, collective and social consciousness and the spiritual rebirth of Russia", "to information security of the Russian Federation's state policy", "to the development of the domestic information industry", "to the security of information and telecommunication measures and systems". Such a division was not introduced in 2016, with all the risks included in the third chapter: "The main information threats and the status of information security". Both doctrines highlighted: a threat to the spiritual life and the functioning of the information space in the individual, collective and social spheres; the relation between the advancement of information technologies with the possibility of manipulating the consciousness (albeit in 2016 it was added that it increasingly serves states in pursuing their "military and political" goals and, as it was repeatedly pointed out, to undermine the sovereignty and territorial integrity of states); the danger of the Russian information industry becoming dependent on Western technologies (the new doctrine states that this condition makes the socio-economic development of Russia reliant on the geopolitical interests of other countries); insufficient academic staff in the field of information technology and the use of electronic tools to obtain information. The most important threats which were not repeated included a point about the threat of monopolisation, especially by foreign information structures, of the Russian information market, ${ }^{26}$ while the list of threats regarding technical issues (data protection, network connections, etc.) became reduced and more general, and points related to the lack of citizens' access to information originating in the structures of the state were removed. Threats in the new doctrine were formulated so as to highlight the increasing danger from other states in the sphere

25 Доктрина информационной, 2000, http://primorsky.ru/authorities/executive-agencies/departments/information-security/Documents/doki-po-ib (accessed: 9 January 2017); Доктрина инбормационной, 2016, http://www.scrf.gov.ru/documents/6/5.html (accessed: 9 January 2017).

26 Western specialists have majorly contributed not only to providing Russia with various technologies, but have also shared their experience, as exemplified by a team of Western consultants responsible for creating modern Russian television (officially for the democratisation of Russia). One of such consultants was Angus Roxburgh, the author of the book The Strongman: Vladimir Putin and the Struggle for Russia, published in 2012. 
of information, stressing the "use of technological advantage for domination in the information sphere", and points have been added regarding the international aspect of information security, which highlighted, according to the authors, the unjust distribution of resources for the functioning of the internet and major difficulties in creating "strategic stability and equal strategic partnership". Some threats have been formulated so as to give the impression that Russia is behind the West in terms of technology. Despite the fact that, for instance, in terms of using modern technology and the internet to control and impact the society (also abroad) Russia can already apply advanced tools. The listed threats reflect the aggressive, in fact, Russian actions, aimed both to increase control over its own society, and to actively impact on the sphere of information in foreign countries.

Officially, therefore, the 2016 doctrine is defensive in nature ${ }^{27}$ and serves shifting the blame for the increased threats in the sphere of information to the West, the evidence of which is to be the latter's technological advantage over Russia. It explains the Russian defensive expansion of its information security, and raises its rank by demonstrating that the use of information technologies can lead to war (the Federation claims the right to strategic deterrence and prevention in the case such threat should arise). Among other activities in the field of defence are the following: "improving the information security system of the Russian Armed Forces, other armed forces, military formations and organs, including the forces and means of information defence; forecasting, detection and evaluation of information threats, including threats to the Armed Forces of the Russian Federation in the sphere of information; help in defending the interests of the Federation's allies in the sphere of information; neutralising the impact of informational and psychological operations directed at the violation of historical foundations and patriotic traditions related to defending the homeland". ${ }^{28}$ This line of thinking has been developed in the later subsections, including those on ensuring information security within state and social security: "preventing the use of information technologies to spread propaganda, extremist ideologies, xenophobia, national discrimination in order to challenge national sovereignty, political and social stability, forceful changes of the constitutional regime, breach of the Russian Federation's territorial sovereignty; preventing the use of [...] information technologies by special services, organisations of other countries and individuals; strengthening the protection of critical information infrastructure and the continuity of its activity, developing fighting mechanisms, staying ahead of the information threats and eliminating

27 "The strategic objective of providing information security in the field of state defence is to: protect the vital interests of individuals, the society and the state from internal and external threats related to the use of information technologies for military and political purposes, against international law, including its use for enemy activities and acts of aggression aimed at undermining sovereignty, violating the territorial integrity of states, and threatening international peace, its security and strategic stability”, Доктрина информационной.., 2016, pp. 8-9.

28 Доктрина информационной, 2016, pp. 8-9. 
their symptoms [...]; increasing the security of the operation of the information infrastructure in order to ensure constant communications between the state authorities, preventing foreign control over these connections, securing the permanent functioning and safety of the merged ICT network of the Federation and the security of information passed and processed within it $[\ldots] ;[\ldots]$; securing the protection of information containing data comprising state secrets $[\ldots] ;[\ldots]$; increasing the efficiency of information security for the Federation's foreign policy; neutralising the efforts to weaken the traditional spiritual and moral values" ${ }^{29}$

Differences in doctrines stem from i.a. a change in the international political situation (partly due to the obsolescence of certain threats). ${ }^{30}$ The new doctrine uses a much more aggressive (implicitly anti-NATO) rhetoric, expanding only on threats selected from the previous document in order to highlight the increasing danger for Russia, and to justify its aggressive actions and intimidating its potential opponents. The approach presented in the doctrines, including the types of threats defined, indicates the points which Russia considers to be particularly sensitive in democratic political systems.

\section{Commentary on doctrines}

Russian information security doctrines do not have NATO counterparts. ${ }^{31}$ In the NATO countries, the issue of information appears in the context of threats discussed in the doctrines of cybersecurity, while in Russian documents the internet is only a part of the wider information environment. This does not mean that the new technologies related to the development of the internet have been ignored in Russia, on the contrary - Russia has quickly realised that their use in a reflexive control paradigm can be highly dangerous for its opponents. ${ }^{32}$ Thinking in these

29 Доктрина информационной, 2016, pp. 9-10. Items on the strategic objectives and main directions of ensuring information security have been defined for the areas of: economy, academia, technology and education, as well as preserving strategic stability and equal international partnership.

30 The objectives that have not been included in the new doctrine (having already been achieved): the provision of state information monopoly, abolition of foreign information structures, development of state associations and information agencies, use of certified means of communication, analysis of foreign information warfare methods, and announcements of preparing relevant legislation. The last independent television station (NTV) was closed, almost at the same time as the doctrine was introduced, by court order in 2001, D. Carman, "Translation and Analysis of the Doctrine of Information Security of the Russian Federation: Mass Media and the Politics of Identity", Pacific Rim Law \& Policy Journal, 11 (2002), no. 2, p. 364.

31 The only European country with such a doctrine is Ukraine: Доктрина інформаційної безпеки України, 29 December 2016, http://www.president.gov.ua/documents/472017-21374 (accessed: 13 April 2017).

32 The Russian approach is effectively presented in the article by Alexander Soloviev, head of the department of political analysis at the Moscow State University: “Культурные последствия 
categories is a domain of the Federation's elite, which derives mainly from the security services of the former USSR. The 1990s were a period of weakness for the Russian State, and of apparent openness to the West. The year 1999, when the young colonel of the KGB/FSB Vladimir Putin assumed the role of the acting president, marked a change of the Russian narrative, which in a nutshell could be described as neo-imperial. As a result of the 2000 elections he became the president and within just a few months signed two new doctrines: on war and on information security. ${ }^{33}$ The latter had already been prepared in $1994,{ }^{34}$ however it had to await the right moment to be officially announced. ${ }^{35}$ How important a role information security has played in Russia's political strategy can be evidenced not only by the published doctrine, but also by the 2001 initiative of the Security Council of Russia and its State Duma Committee to launch the first InfoForum. ${ }^{36}$ The implicit aim in the doctrine, to consolidate the former USSR and restore its spheres of influence, required obtaining information dominance within Russia and other areas of its interest. A close reading of threats presented in the 2000 doctrine leads to two main conclusions:

a. in 2000 , the Kremlin was already in the process of increasing political control of society, imposing a new ideology, establishing the state's information monopoly, developing the activities of public associations and news agencies, analysing the suitability of new technologies to purposes of war, introducing new legislation;

применения новых коммуникаций (поддерживаемых современными электронными СМИ [Social Media Information]) в значительной степени делают иллюзорными национальные политические границы. [...] Но приведет ли это к какой-то разновидности изоляции российского общества или под блиянием новых политикокультурных реалий изменится государственно-административная форма прабления", А.И. Соловьев, “Информационно-коммуникативные процессы в современном мире: социокультурные иллюстрации”, in: Современная российская политология, Москва, 2003, pр. 327, 335-336.

33 Доктрина информационной, 2000, http://www.scrf.gov.ru/documents/5.html (accessed: 9 January 2017).

${ }^{34}$ Carman, Translation and Analysis, p. 343.

35 The document's publication was met with apprehension in Russia itself, for instance among journalists and historians who feared restrictions on freedom of speech and penalties for interpretations of history incompatible with the state one, http://www.rbc.ru/politics/06/12/2016/5846872e9a794718be9693c3 (accessed: 17 May 2017), D. Carman, Translation and Analysis, p. 345.

${ }^{36}$ https://InfoForum.ru/about-InfoForum (accessed: 10 May 2017). The doctrine on information security (National Information Security Forum) officially serves the exchange of ideas, but in practice is a dummy of Western mechanisms. It builds a sense of community involvement in the process of creating information policy, supports its implementation ("programming" the society), and encourages citizens to engage in information campaigns against the enemies of Russia. The event has been held regularly since 2001, and in recent years attended by about a thousand participants each time - both representatives of central administration (i.a. ministers of National Defence and Foreign Affairs), territorial and military administration, as well as Duma members, and specialists (IT professionals, journalists, academics, businessmen, NGO and GONGO members). 
b. the manner in which the threats were perceived in the doctrine reflected the weakness of democratic systems, which in combination with Russia's current activities is a good indicator of actions the West is exposed to, as it shows the specificity of the Russian thought.

The new Doctrine on information security was approved on 5 December 2016, five days after the publication of The foreign policy concept of the Russian Federation. The documents thus replaced the Doctrine on information security of the Russian Federation which entered into force on 9 September 2000 (amended in 2013) and The foreign policy concept of the Russian Federation from 12 February 2013. Completion of the new doctrine was announced at the beginning of 2016, during the InfoForum held on 4-5 February. ${ }^{37}$ On 24 June 2016, a project appeared on the website of the Security Council of the Russian Federation, with an appeal to citizens to submit their comments. ${ }^{38}$ This is an example of preserving, for propaganda reasons, the appearances of democratic mechanisms during the works on the document. Russian doctrine was published 12 days after the European Parliament adopted the resolution on misinformation and propaganda practiced by Daesh and Russia. It is possible that the Kremlin waited until the European Parliament voted on the resolution in order to emphasise the defensive nature of its own doctrine, which comprised items identical to Putin's statement about it ${ }^{39}$ and other statements accusing the West of introducing censorship, restricting the freedom of expression, and discriminating against Russian journalists. ${ }^{40}$

An element characteristic of both doctrines is prioritising information over technology and information security, rather than putting the way it is communicated

37 Результаты Инфофорума-2016 "Информационная безопасность России в условиях глобального информационного общества”, 12 February 2016, http://www.securitylab.ru/news/479412. php (accessed: 30 September 2016).

38 Доктрина информационной безопасности Российской Федерации (проект), “Будем признательны за конструктивные предложения по проекту новой редакции Доктрины информационной безопасности РФ. Благодарим за проявленный интерес!”, http://www.scrf.gov. ru/news/1098.html (accessed: 30 December 2016).

39 Putin has stated that the resolution violated democratic standards and expressed hope that the West would therefore decide not to take action against Russian journalists - "Если такое решение принято, это говорит о том, что мы наблюдаем совершенно очевидную деградацию в политическом смысле этого слова представлений о демократии в западном обществе. [...] нас пытались учить демократии, и всегда мы от этих “учителей” слышали, что самый порочный способ вести дела с оппонентами - это что-то запрещать, и это не соответствует принципам и нормам демократии. А лучшим способом является всегда открытая дискуссия. [...] Очень рассчитываю на то, что здравый смысл восторжествует и реально никаких ограничений мы здесь не увидим", http://tass.ru/politika/3807411 (accessed: 9 January 2017). The spokeswoman for the Ministry of Foreign Affairs Maria Zakharova has announced that the Russian response would be symmetrical.

40 See: Vladimir Putin's speech from October 2016 at the annual meeting of the Valdai Club and before the Federal Assembly on 1 December 2016; http://kremlin.ru/events/president/news/53151, http://kremlin.ru/events/president/news/53379 (accessed: 16 January 2017). 
first, hence the word "information" is in main use in Russia instead of the phrase "information technology". Many democratic states find it difficult to understand this approach and develop a suitable remedy. Their actions tend to concentrate around technical issues, related to the protection of information infrastructure. A spectacular example of this was the electoral campaign in the United States, as well as the current political frictions resulting from introducing into the public discourse, next to a large number of false or manipulated information about the candidates, of the question whether Donald Trump and his circles have any agent links with Russia. The Russian attack on Hilary Clinton's email account on the one hand revealed information which was fairly non-essential, but scandalous for the public opinion, on the other - confirmed the argument, popular with Trump's opponents, that he is supported by Russia. As a result, in this operation technological abilities have played only a technical role, while its purpose was to achieve a psychological effect. This example illustrates how Russia attempts to create an image of its omnipotence, and although it officially denies all accusations, the mere suspicions and their escalation, as shown by the above example, are a great success in themselves. The Russian authorities are aware that by using foreign technologies they will not be able to fully control their information space (and society); they will therefore seek to increase the competitiveness of Russian products in the IT industry and to ensure self-sufficiency for themselves in the field of high technology, electronics, computer hardware and software.

The documents consciously utilise Western terminology related to the defence of human and civil rights, in order to introduce conceptual confusion and conceal their true intentions. Russian doctrines are only officially defensive in nature; ${ }^{41}$ their aim is to misinform the external and internal recipient (as the Kremlin aims towards mental, economic and territorial expansion). The content of the doctrine is indicative of an increasingly confrontational direction in the politics of the Russian Federation, resulting not from the fear of new threats, but from the long-accepted strategy and internal situation in Russia, whose consolidation is taking place by maintaining the society's belief in a constant threat from the United States, the EU, terrorists, or foreign nationalists - the new document is a natural continuation of the course officially presented in 2000. These days, we can observe sharper political rhetoric within individual countries and in the international arena, which to some degree is undoubtedly due to the Russian policy of imposing its militarised conceptual matrix on the world. ${ }^{42}$ This applies not only

${ }^{41}$ Pomerantsev has aptly defined the Russian narrative: "The West blows small nations to smithereens, while in Russia they blossom”, P. Pomerantsev, Jądro dziwności. Nowa Rosja, Wołowiec, 2015, p. 229.

42 "A group of theorists using such a conceptual apparatus is growing, simulating a picture of extensive collective support of the Russian authorities". New terms have sprung up, including: information war, information attack, historical weapon, information spetsnaz, civilisation weapon, information weapon, J. Darczewska, "Wojna informacyjna Rosji z Zachodem. Nowe wyzwanie?", 
to the use of Russian terminology in describing the activities of the West, and Western terminology to describe the activities of Russia, but also to the uncritical reception of Russian political thought and science, which in fact fosters the vision of the world promoted by the Russian Federation, justifying Russian aggression and armaments. ${ }^{43}$ The Russian paradigm should be investigated in order to formulate an adequate response, but it cannot be succumbed to.

It is expected that Russia will intensify its actions in the sphere of information, while insisting on the international arena that these are only defensive measures. Meanwhile, the West has neither the traditions nor the abilities, nor legal capacity (democratic procedures) to pursue information politics as centralised and consistent as Russia. Russia partially revealed its plan of action in the doctrine of 2000 . However, only in 2014 did the West begin to pay more attention to Russian actions.

The defensive rhetoric justifies the centralisation of information policy and full control over the information infrastructure in Russia. It is centralised by subordinating all aspects of information politics strictly to the leadership of the Federation - the Security Council of the Russian Federation, ${ }^{44}$ and within it the Information Policy Commission of the Russian Federation ${ }^{45}$ (the most important decisions

in: Przegląd Bezpieczeństwa Wewnętrznego. Wojna hybrydowa. Wydanie specjalne, Warszawa, 2015, p. 71.

43 A part of these activities is the use of Western terminology to describe Russian activities, in order to shift the blame to the Western world, or to justify Russian activities. Such examples include Russia's use of the term hybrid warfare. This term has been coined by American academics, and in the Russian narrative has been used to accuse the West of conducting activities de facto synonymous with the mostly Russian/Soviet paradigm of information war. Thus the war provoked by Russia in Ukraine was described as a hybrid war, which prompted the shift of the blame to the West.

${ }^{44}$ Chairman: President; permanent members: Head of the FSB, Head of Presidential Administration of Russia, Chairman of Duma, Presidential Representative on Environmental Issues and Transport, Minister of Internal Affairs, Minister of Foreign Affairs, Chairman of the Council of the Federation of the Federal Assembly, Prime Minister, Head of the Foreign Intelligence Service, Secretary of the Security Council, Minister of Defence and 18 ordinary members.

${ }^{45}$ Members of the interdepartmental committee of the Security Council of the Russian Federation for information security (updated in May 2015): Deputy Secretary of the Security Council of the RF (Chairman of the commission), Special Representative of the President of the RF for International Cooperation in Information Security, First Vice-President of the Duma Committee for Security and Counteracting Corruption, First Deputy Prime Minister of the RF, First Deputy Minister of Culture of the RF, First Deputy Minister of Education and Training of the RF, Secretary of State - Deputy Minister of Economic Development of the RF, State Secretary Deputy Minister of Energy of the RF, Deputy Minister of Internal Affairs of the RF, Deputy Minister of Industry and Trade of the RF, Deputy Minister of Services and Mass Communication of the RF (Deputy Chairman of the Commission), Deputy Minister of Transport of the RF, Deputy Minister of Justice of the RF, Chief State Inspector for Firefighting, Deputy Head of the Rosfinmonitoring, Deputy Head of the Foreign Intelligence Service, Deputy Head of the Federal Security Service, Deputy Head of the Federal Service of Technical and Export Control, First Deputy Head of the Federal Customs Service, Secretary of State - Deputy Head of the Federal Service for Environmental, Technological and Atomic Energy Supervision, Deputy Head of the 
regarding the directions of this policy are taken within Putin's immediate circle). Centralisation of this policy is favoured by the fact that many management positions in the administration, key academic institutions, ${ }^{46}$ associations and companies which fund them are filled with people from the special forces and the army. The common experiences, knowledge of the same models of activity, one mental code and personal friendships determine the way Russian activities are carried out, promote the effect of synergy, and enable long-term information operations (as confirmed by the types of threats listed in both the information doctrines, such as: weakening traditional Russian spiritual and moral values, which requires a long-term impact). The state media and most of the private ones (a specific model of media functioning has developed, which combines Western technique with Russian methods of manipulating social awareness) follow the information policy (ideology), ${ }^{47}$ internet media (a multilingual network consisting of official information services, websites, blogs, meme, photo and video sharing channels, social networking discussion groups, troll commentators), legislation (disrupting the freedom of speech), ${ }^{48}$ education (at all levels), ${ }^{49}$ opinion poll agencies,

Federal Migration Service, Deputy Head of Roskomnadzor (The Federal Service for Supervision of Communications, Information Technology and Mass Media), Deputy Head of Rospatent (Federal Service for Intellectual Property), Deputy Head of Rospechat (Federal Agency on Press and Mass Communications), Deputy Head of Rossvyaz (Russian Federal Communications Agency), Deputy Head of Rosstat (Federal Service for State Statistics), Deputy Head of the Federal Tax Service, Head of the FSB (Deputy Chairman of the Commission), Head of the Presidential Administration of Russia for Application of Information Technology and the Development of E-Democracy, Head of General Staff of the Armed Forces of the RF - Deputy Head of the General Staff of the Armed Forces of the RF, Deputy Head of the Board of Special Programs of the President of the RF, Deputy Head of the Board of the Press and Information Service of the President of the RF, referent of Security Council of the RF, referent of the Information and Data Security Board of the President of the RF, Head of the Department of the Security Council camera of the RF (Secretary of the Commission), Head of the Department of the Government Apparatus of the RF, Vice-President - Head of security services of the Rosneft, Deputy Chairman of the Board of Gazprom; http://www.scrf.gov.ru/about/commission/MVK_info_members/ (accessed: 13 May 2017).

${ }^{46}$ Research into not just geopolitics, but also information security has developed considerably in Russia, see: Russian Institute for Strategic Studies (until January 2017 headed by the candidate of historical sciences, General Colonel of the SVR Leonid Reshetnikov, currently former head of the SVR Mikhail Fradkov); Institute of Cryptography, Telecommunications and Computer Science of the Academy of the Federal Security Service of Russia, Institute for Information Security Issues of the Lomonosov Moscow State University (Colonel general of the KGB Vladislav Sherstyuk), http://www.iisi.msu.ru, https://riss.ru (accessed: 12 January 2017).

47 Pomerantsev, Jądro dziwności, p. 288.

48 The introduction of relevant provisions was preceded by a series of subversive incidents involving Pussy Riot, presented as an outpost of the "rotten West" (it is possible that this was a provocation of the services, aimed to increase the Russians' acquiescence to tighten some of the rules).

49 Students of military schools are subject to particular influence, i.a. in the Cadet Corps, P. Jastrzębski, "Wschodni model wychowania państwowego na przykładzie rosyjskiego korpusu kadetów. Zarys problemu", Wschodni Rocznik Humanistyczny, 8 (2012), pp. 145-152. 
culture, ${ }^{50}$ entertainment (including computer games), ${ }^{51}$ science, ${ }^{52}$ publishing houses ${ }^{53}$ the Orthodox Church, ${ }^{54}$ "non-governmental" organisations (also international, funded by state-owned companies such as Gazprom or Rosneft), ${ }^{55}$ paramilitary youth organisations,${ }^{56}$ paramilitary groups,${ }^{57}$ Russian cultural and language learning centres outside the Russian Federation. ${ }^{58}$

\section{Conclusions}

Russia's actions since 1991 have evolved from consolidating the society, deterrence and attempts to maintain its former sphere of influence, to offensive actions,

${ }^{50}$ For example, the attack on Ukraine was preceded by a propaganda campaign in popular culture (well illustrated by the television series The White Guard, in which positive heroes are both white and red (in contrast to the Ukrainians, who opposed the unity of the lands of the Empire). Reminders of Russia's alleged humiliations at the hands of Poles play a significant role in mobilising the Russian society, highlighting the Polish Russophobia, as does the role of the Vatican, and especially of the Jesuits, in the fight against Orthodox Christianity; see Sophia (new television series subsidised by the Orthodox Church and the Ministry of Defence of the RF).

${ }^{51}$ Dissemination of Russian propaganda through instant messaging of online games and their plot promoting the myth of a victorious patriotic war.

52 Spectacular examples of subordinating academic goals to the information doctrine is the takeover of the Russian Historical Society by the Head of the SVR Sergey Naryshkin, of the Russian Geographical Society by the Minister of National Defence General Sergey Shoygu (President of the supporting council of the Society is Vladimir Putin), or of the Academy of Geopolitical Problems by Colonel General Leonid Ivashov, http://rushistory.org/, https://www.rgo.ru, http:// akademiagp.ru/ (accessed: 12 January 2017). Geopolitics are taught at all higher education institutions, and a wide range of textbooks are available online, for example: Б. Исаев, Геополитика. Учебник для вузов. Стандарт третьего поколения, 2016; А. Дугин, Геополитика. Учебное пособие, 2015.

${ }^{53}$ For example, related to the FSB publishing house "Veche", which releases books mostly on history, political science and literature, http://www.veche.ru/ (accessed: 17 May 2017).

54 The Imperial Orthodox Palestine Society merged with the Centre for the Development of Eastern Christianity (headed by Sergei Stepashin, former head of FSB), http://www.ippo.ru (accessed: 12 January 2017).

55 For example, CIS-EMO, an organisation dedicated to "monitoring" democratic standards, A. Shekhovtsov, "Far-right Election Observation Monitors in the Service of the Kremlin's Foreign Policy", in: Eurasianism and the European Far Right: Reshaping the Europe-Russia Relationship, ed. M. Laruelle, 2015, p. 224-226.

56 September 2016 saw the creation of a youth army, an organisation of children aged 11 to 18 .

57 For example: "Night Wolves", Cossack organisations, nationalist groups, hacker groups (Fancy Bears, Cozy Bear, which are probably undercover regular units of Russian special forces or the army).

58 The Russkiy Mir organisation has counted the Russian diaspora, people using the Russian language worldwide, and institutions teaching the Russian language (it has been found that the Podlaskie, Mazowieckie, Lubelskie and Podkarpackie voivodships in Poland gravitate towards the east; Russian is more popular in school education in these areas), http://russkiymir.ru/catalogue/catalog.php?country=60 (accessed: 13 January 2016). 
launched with an attack on Georgia in 2008. The progressing intensification of activities since 2014 cannot be perceived as defence against the expansion of NATO and the EU. The aggressive attitude of Russia derives from the doctrine it has accepted. The restoration of Russia's potential and the international situation, conducive to conflict, allows it take more decisive disintegrative actions towards NATO and the EU, whose aim is to change the geopolitical system.

The new Doctrine on information security of the Russian Federation continues the politics presented in the 2000 doctrine, with sharper rhetoric. Intensified Russian activities in the area of information from 2014 onwards are an outcome of the continuity of thought, evidenced by the presented doctrines. Apart from the official update of challenges and threats, the doctrine primarily serves the Russian information strategy (as a part of strategic misinformation), within which it acts as:

a. propaganda - it consolidates the society, accuses other countries of aggressive actions, creates the impression that Russia has a new, dangerous doctrine and it is ready to "defend" the Russkiy Mir, provides a ready-made narrative for foreigners supporting the Federation, and contributes to building a positive image of the president;

b. misinformation - it hides the actual intentions of the authorities, supports the thesis of the defensive character of Russian activities (the actions cannot be analysed without taking into account the moves taken in the previous two decades), and conceals the degree of the advancement of the Russian information technology.

Reading the latest Doctrine of information security in the context of other documents and activities taken by the Russian Federation's authorities shows that:

a. the content of doctrines reveals the Russian way of thinking and allows to determine what actions can be expected from the Russian side: influencing individual, collective and social awareness, especially in young people, ${ }^{59}$ in order to fuel international, religious, ethnic and social tensions;

b. Russia's activities in the infosphere are characterised by combining instruments from the field of humanities and sciences, and its approach is dominated by the primacy of psychology, meaning that there is a particular focus on developing methods designed to impact on human perception, attitudes, mentality and emotions;

c. the publication of the doctrine and further actions aimed to increase Russian capabilities in the information sphere indicate that the Kremlin highly values the effectiveness of its information operations so far and intends to intensify it both on the internal and external basis; ${ }^{60}$

59 It is fostered by the fading memory of World War II and the Polish People's Republic, an insufficient number of teaching hours of history in schools, and new, often unreliable sources of information, such as the internet.

${ }^{60}$ Destabilisation activities can become more prominent during election campaigns, intensified political conflicts and international disputes. The Polish specificity means that memorial spots will continue to be sensitive, both those related to the Red Army and the UPA, as well as incidents 
d. the Russian authorities are trying to impose on the world its paradigm of information wars, coupled with heavily promoted geopolitics, in order to smuggle through its vision of international relations and creating an atmosphere favouring the use of forceful solutions;

e. in order to deter and hide its real capacities, Russia is trying to create a picture of its omnipotence (although officially it denies it). To this end it stresses i.a. the importance of the new doctrine, or the establishment of a new kind of army "for information operations" 61 (it also reserves the possibility of a kinetic response to information threats);

f. the construction of the Russian world, or its empire, will require a continued ideological influence, within the framework of such concepts as: the Russkiy Mir (and, within it, pan-Slavism), ${ }^{62}$ Eurasian Union and the Fourth Political Theory (representing liberal democracy as the last functioning totalitarian system). These concepts have both common and mutually exclusive elements. This makes it possible to find a larger group of recipients for the ideas, leading de facto to one goal, which is to change the geopolitical system to one in which Russia can gain a better position.

In conclusion, the role of the new information security doctrine should not be underestimated. The approach it presents is a continuation of the Soviet military thought. Russian services have quickly and naturally discerned the potential benefits of applying new technologies within the framework of the old methods of impact, misinformation, etc. These observations had already been made in the 1990s, in the 2000s capabilities developed in this direction, and for at least a few years intense activities have been carried out using the internet. Based on the doctrines on information security, we can observe that Russia has precisely identified the gaps in democratic systems and will consistently use them, which constitutes a threat also to the stability of the Polish state.

which may arise, among other things, on the line Poland-Ukraine (it is possible that in the future, due to external actions, conflicts with other states, nationalities or ethnic groups living in Poland will be provoked).

${ }^{61} \mathrm{http} / / /$ www.pap.pl/aktualnosci/news,816344,rosja-szojgu-o-istnieniu-oddzialu-zolnierzy-wojnynformacyjnej.html (accessed: 26 May 2017).

62 See i.a. portal: Западная Русь: Рубеж Святой Руси в прошлом, настоящем и будущем, with a bookmark on Polish issues. Contributors to the website include analysts associated with Russian Institute for Strategic Studies; one of the regular contributors is Oleg Nemenskiy https:// zapadrus.su/bibli/geobib/2011-08-03-16-33-54.html (accessed: 17 May 2017). 


\section{Bibliography}

\section{Documents}

Военная доктрина Российской Федераиии, 2000, http://www.ng.ru/politics/2000-04-22/5_ doktrina.html.

Военная доктрина Российской Федерации, 2010, http://kremlin.ru/supplement/461.

Военная доктрина Российской Федерации, 2014, http://kremlin.ru/events/president/ news/47334.

Доктрина информационной безопасности Российской Федерации, 2000, http://primorsky. $\mathrm{ru} /$ authorities/executive-agencies/departments/information-security/Documents/dokipo-ib.

Доктрина инбормационной безопасности Российской Федерации, 2016, http://www.scrf. gov.ru/documents/6/5.html.

Доктрина Русского мира, авторский коллектив доклада: В. Аверьянов, С. Баранов, А. Гапоненко, А. Елисеев, А. Комогорцев, А. Стариков, 26.09.2016,

https://izborsk-club.ru/10269.

Доктрина інформаційної безпеки України, 2016, http://www.president.gov.ua/ documents/472017-21374.

Дугин А., Геополитика. Учебное пособие, 2015.

Исаев Б., Геополитика. Учебник для вузов. Стандарт третьего поколения, 2016.

Основные положения военной доктрины российской феедерации, 1993, http://studydoc.ru/ doc/360885/osnovnye-polozheniya-voennoj-doktriny-rossijskoj-federacii.

Русская Военная Доктрина. Материалы дискуссий 1911-1939 годов, изд. А. Савинкин, Москва 1994.

Соловьев А.И., Информационно-коммуникативные процессы в современном мире: социокультурные иллюстрации, in: Современная российская политология, Москва 2003.

Чубаткин Д.Н., Военная доктрина как способ информационного воздействия (семиотический подход), in: Современная Россия и мир: альтернативы развития (Информаизинные войны в международных отношениях), ред. Ю.Г. Чернышов, Барнаул 2012, pp. 136-140.

\section{Secondary literature}

Bączkowski W., "Uwagi o istocie siły rosyjskiej”, Wschód-Orient, 1938, no. 4, http://www.omp. org.pl/artykul.php?artykul=115.

Bączkowski W., Rosja wczoraj i dziś, Jerozolima, 1946.

Besançon A., "Imperium rosyjskie i panowanie sowieckie", in: Sowietskij Sojuz. Wybór, eds. J. Karpiński, I. Lasota, Wrocław, 1989, pp. 7-18.

Carman D., "Translation and Analysis of the Doctrine of Information Security of the Russian Federation: Mass Media and the Politics of Identity", Pacific Rim Law \& Policy Journal", 11 (2002), no. 2, pp. 339-369.

Clausevitz C., O wojnie, Warszawa, 2010.

Darczewska J., Rosyjskie sity zbrojne na froncie walki informacyjnej. Dokumenty strategiczne, Warszawa, 2016 (series: Prace OSW, no. 57).

Darczewska J., "Wojna informacyjna Rosji z Zachodem. Nowe wyzwanie?", in: Przeglą Bezpieczeństwa Wewnętrznego. Wojna hybrydowa. Wydanie specjalne, Warszawa, 2015, pp. 59-73.

Garthoff R.L., Soviet military doctrine, Illinois, 1953. 
Głuszkowski P., Antyrosja. Historyczne wizje świata Aleksandra Sołżenicyna. Próba polskiego odczytania, Warszawa, 2008.

Gołąbek B., Lew Gumilow i Aleksander Dugin. O dwóch obliczach euroazjatyzmu w Rosji po 1991 roku, Kraków, 2012.

Jastrzębski P., "Wschodni model wychowania państwowego na przykładzie rosyjskiego korpusu kadetów. Zarys problemu”, Wschodni Rocznik Humanistyczny, 8 (2012), pp. 145-152.

Jones R.A., The Soviet Concept of "Limited Sovereignty" from Lenin to Gorbachev: The Brezhnev Doctrine, London, 1990.

Martin L., "The Influence of Soviet Military Doctrine on Western Strategy", in: Soviet Military Doctrine and Western Policy, ed. G. Flynn, London, 1989.

Pomerantsev P., Jądro dziwności. Nowa Rosja, Wołowiec, 2015.

Reid C., "Reflexive Control in Soviet Military Planning", in: Soviet Strategic Deception, ed. B.D Dailey, P.J. Parker, Toronto, 1987, pp. 295-311.

Roxburgh A., Strongman u szczytu władzy. Władimir Putin i walka o Rosję, Warszawa, 2012.

Shekhovtsov A., "Far-right Election Observation Monitors in the Service of the Kremlin's Foreign Policy", in: Eurasianism and the European Far Right: Reshaping the Europe-Russia Relationship, ed. M. Laruelle, Lexington Books, 2015, pp. 223-243.

Wojnowski M., "Koncepcja wojny sieciowej Aleksandra Dugina jako narzędzie realizacji celów geopolitycznych Federacji Rosyjskiej”, Przegląd Bezpieczeństwa Wewnętrznego, 16 (2017), pp. 11-37.

Wojnowski M., “'Zarządzanie refleksyjne’ jako paradygmat rosyjskich operacji informacyjno-psychologicznych w XXI w.", Przegląd Bezpieczeństwa Wewnętrznego, 12 (2015), pp. 11-36.

Wraga R., "Gwarancje Pana Otmara”, Bunt Młodych, 13 May 1935, no. 10, pp. 4-5.

Wraga R., Geopolityka, strategia i granice, Tel Awiw, 1943.

Wraga R., “O tak zw. 'Komuniźmie narodowym”, Syrena, no. 48, 1 December 1956.

\section{Websites}

http://www.rp-net.ru/book/OurAutors/struve/index.php

http://www.rusdoctrina.ru/page95504.html

http://tass.ru/politika/3807411

http://kremlin.ru/events/president/news/53151, http://kremlin.ru/events/president/news/53379 http://russkiymir.ru/catalogue/catalog.php?country=60

http://www.pap.pl/aktualnosci/news,816344,rosja-szojgu-o-istnieniu-oddzialu-zolnierzy-wojnynformacyjnej.html

https://zapadrus.su/bibli/geobib/2011-08-03-16-33-54.html

http://www.ippo.ru

http://www.scrf.gov.ru/about/commission/MVK_info_members/

http://www.iisi.msu.ru, https://riss.ru

http://www.securitylab.ru/news/479412.php

http://rushistory.org/

https://www.rgo.ru, http://akademiagp.ru/

Eukasz Dryblak, PhD student in the Institute of History of the Polish Academy of Sciences. Research interests: Polish-Russian relations, Russian exile, military history, ethnic policy of the Second Polish Republic (lukaszdryblak7@wp.pl). 